\title{
Functional reconstitution of RLIP76 catalyzing ATP-dependent transport of glutathione-conjugates
}

\author{
SHARAD S. SINGHAL, ARCHANA SEHRAWAT, AMEE MEHTA, MUKESH SAHU and SANJAY AWASTHI \\ Department of Molecular Biology and Immunology, University of North Texas \\ Health Science Center, Fort Worth, TX 76107-2699, USA
}

Received August 22, 2008; Accepted September 30, 2008

DOI: 10.3892/ijo_00000141

\begin{abstract}
RLIP76, a stress-responsive, multi-functional protein with multi-specific transport activity towards glutathioneconjugates (GS-E) and chemotherapeutic agents is frequently overexpressed in malignant cells. Our recent studies suggest that it plays a prominent anti-apoptotic role selectively in cancer cells. The present studies were performed to compare RLIP76 activity towards glutathione-conjugates in recombinant and K562 human erythroleukemia cells. The purity and identity of recombinant and K562 RLIP76 was established by SDSPAGE and Western blot analysis. These studies confirmed the origin of the $38 \mathrm{kDa}$ protein, previously referred to as DNP-SG ATPase, from RLIP76. Comparison of ATPase activity and transport kinetics for DNP-SG and GS-HNE between recombinant vs. K562 RLIP76 revealed higher specific activity of ATPase and transport for recombinant purified RLIP76, indicating that additional factors present in recombinant purified RLIP76 can modulate its transport activity.
\end{abstract}

\section{Introduction}

Glutathione (GSH) is used in the mercapturic acid pathway for metabolism of electrophilic compounds. GST the rate limiting enzyme of mercapturic acid biosynthesis, catalyzes the formation of the first product in this pathway, glutathioneelectrophile-conjugates (GS-Es). The next conversion of GS-E, hydrolysis of the glutamic acid residue is catalyzed by $\gamma$-glutamyl transpeptidase (GGT), located on the extracelluar membrane surface. Thus, the next step in mercapturic acid

Correspondence to: Dr Sharad S. Singhal, Department of Molecular Biology and Immunology, 3500 Camp Bowie Blvd., University of North Texas Health Science Center, Fort Worth, TX 76107-2699, USA

E-mail: ssinghal@hsc.unt.edu

Abbreviations: RLIP76 (RalBP1), Ral-interacting protein; GSH, glutathione; GS-E, glutathione-electrophile-conjugates; DNP-SG, dinitrophenyl S-glutathione; 4HNE, 4-hydroxynonenal; GS-HNE, glutathione-conjugate of 4HNE; IOVs, inside-out vesicles

Key words: RLIP76, K562, 4HNE, drug-resistance, glutathioneconjugate, transport biosynthesis is the ATP-dependent efflux of GS-E into extracellular space. Our studies have shown that RLIP76 is the predominant transporter of GS-E (1-4), thus functions to protect cells from electrophilic/oxidant/radiant stressors.

RLIP76, a protein cloned previously by others as a Raleffector and Ral-GAP that bridged the Ras and Ral pathways, and displayed GAP activity towards Rho/Rac G-proteins (5-7). In independent studies seeking the genetic identity of DNPSG ATPase, a multi-specific transporter protein (8-10), we established the identity of DNP-SG ATPase as RLIP76 (1-4,11-14). We have extensively studied the catalytic activity of RLIP76, a purified and authenticated protein, in artificial cholesterol: phospholipid membranes, and demonstrated transport of a number of xenobiotic compounds and GS-E. Concomitantly, previous studies by other investigators indicate that RLIP76 plays a crucial role in clathrin-coated pit-mediated receptor/ligand-pair endocytosis, particularly as related to TGFß, EGF, and insulin (15-17). Other investigators have shown that binding of cdc2 to RLIP76 is essential to shut off endocytosis during mitosis (16) and overexpression of POB1 (partner of RLIP76, the first described RLIP76 binding protein) triggers apoptosis in prostate cancer cells (18).

Relevance of these findings generally to cancer drugresistance are based not only in observations by others of the seminal roles of each of the above RLIP76-interacting pathways in carcinogenesis and cancer pharmacology, but also because of the relatively promiscuous nature of RLIP76 with respect to substrate specificity such that numerous amphiphilic chemotherapy drugs can function as transported substrates and as competitive inhibitors of its physiological function, GS-E efflux. A direct implication of our findings is that the execution of endocytosis, mitosis, and apoptosis is regulated by signaling pathways such as Ral, Ras, Rho/Rac and CDK1 by regulation of the rate of efflux of physiological pro-apoptotic GS-E by RLIP76 which couples ATP-hydrolysis linked with GS-E transport $(11,12)$. Additional results by other investigators have also shown that dissociation of RLIP76 from membrane upon binding with cdc2 results in translocation to the mitotic spindle $(16,19)$ where, given its ATPase activity to provide energy for spindle movement; these studies suggest a more generalized hypothesis that RLIP76 functions as a modular ATPase that provides energy to different cellular protein by binding to different adaptor proteins.

The relationship between phase III biotransformation and apoptosis can be chemically explained by a well accepted model of stress-mediated apoptosis, in which external 
chemical/radiant stressors which cause membrane lipid oxidation give rise to reactive lipid oxidation products, 4hydroxynonenal (4HNE), which are pro-apoptotic lipophilic electrophiles subject to direct phase II biotransformation into GS-E through GST-mediated catalysis. Since GSTs catalyze Michael-addition between alkenals and GSH (20), and because GS-E formed from alkenals are generally excellent product inhibitors of GSTs (21), the removal of GS-E is critical for maintaining GST activity and efficient metabolism of pro-apoptotic alkenals. Affinity purification aimed at a membrane ATPase activity stimulated by GS-E led to the eventual identification of RLIP76 as a GS-E and multidrug resistance protein which plays a key anti-apoptotic function in survival of cancer cells. In the present studies, we compared the ATPase activity and transport properties of RLIP76 purified from recombinant and K562 human erythroleukemia cells, towards glutathione-conjugates.

\section{Materials and methods}

Tissue culture supplies were purchased from Gibco BRL Inc. (Grand Island, NY). Ninety-six well nitrocellulose plates (pore size $0.45 \mu \mathrm{m}$ ) used in transport studies were procured from the Millipore Corp. (Bedford, MA). 4-HNE was purchased from Cayman Chemical Co. (Ann Arbor, MI). ${ }^{3} \mathrm{H}-\mathrm{GSH}$ $(3,000 \mathrm{Ci} / \mathrm{mmol})$ was purchased from Pharmacia Biotech (Piscataway, NJ). ${ }^{3} \mathrm{H}-\mathrm{DNPSG}$ (specific activity $3.6 \times 10^{3} \mathrm{cpm} /$ $\mathrm{nmol}$ ) and ${ }^{3} \mathrm{H}-\mathrm{GSHNE}$ (specific activity $3.5 \times 10^{4} \mathrm{cpm} / \mathrm{nmol}$ ) were synthesized according to the method described by us previously (14). Polyclonal rabbit anti-human-RLIP76 IgG were prepared and purified as described earlier (1).

Purification of RLIP76 from K562 cells. The K562 (human erythroleukemia) cell lines were purchased from American Type Culture Collection, Manassas, VA, and were grown in RPMI-1640 medium supplemented with $10 \%$ (v/v) FBS and $1 \%(\mathrm{v} / \mathrm{v}) \mathrm{P} / \mathrm{S}$ solution. Cells were maintained at $37^{\circ} \mathrm{C}$ in a humidified atmosphere of $5 \% \mathrm{CO}_{2}$. Affinity purification of RLIP76 from K562 cells was carried out in a manner identical to that described for lung cancer cell lines (11). Purifications were monitored by measuring ATPase activity. ATPase activity determination, SDS-PAGE and Western blot analyses to analyzed purified protein, and protein estimation were performed as previously described (11).

Purification of RLIP76 from transformed E. coli. We have shown that a DNP-SG affinity resin prepared as previously described by us can be used to purify RLIP76 to near homogeneity (1). Recombinant human RLIP76 was purified from 1 liter cultures of $E$. coli BL21 expressing the full-length RLIP76 cDNA in PET30a (+) prokaryotic expression plasmid. Purity was checked by Western blot analysis, and MALDIMS.

Reconstitution of purified RLIP76 into artificial liposomes. Purified RLIP76 from K562 cells as well as from recombinant source was reconstituted into artificial asolectin-cholesterol liposomes. Control-liposomes were prepared using an equal amount of crude protein from $E$. coli not expressing RLIP76 (1). The size of reconstituted vesicles was examined by

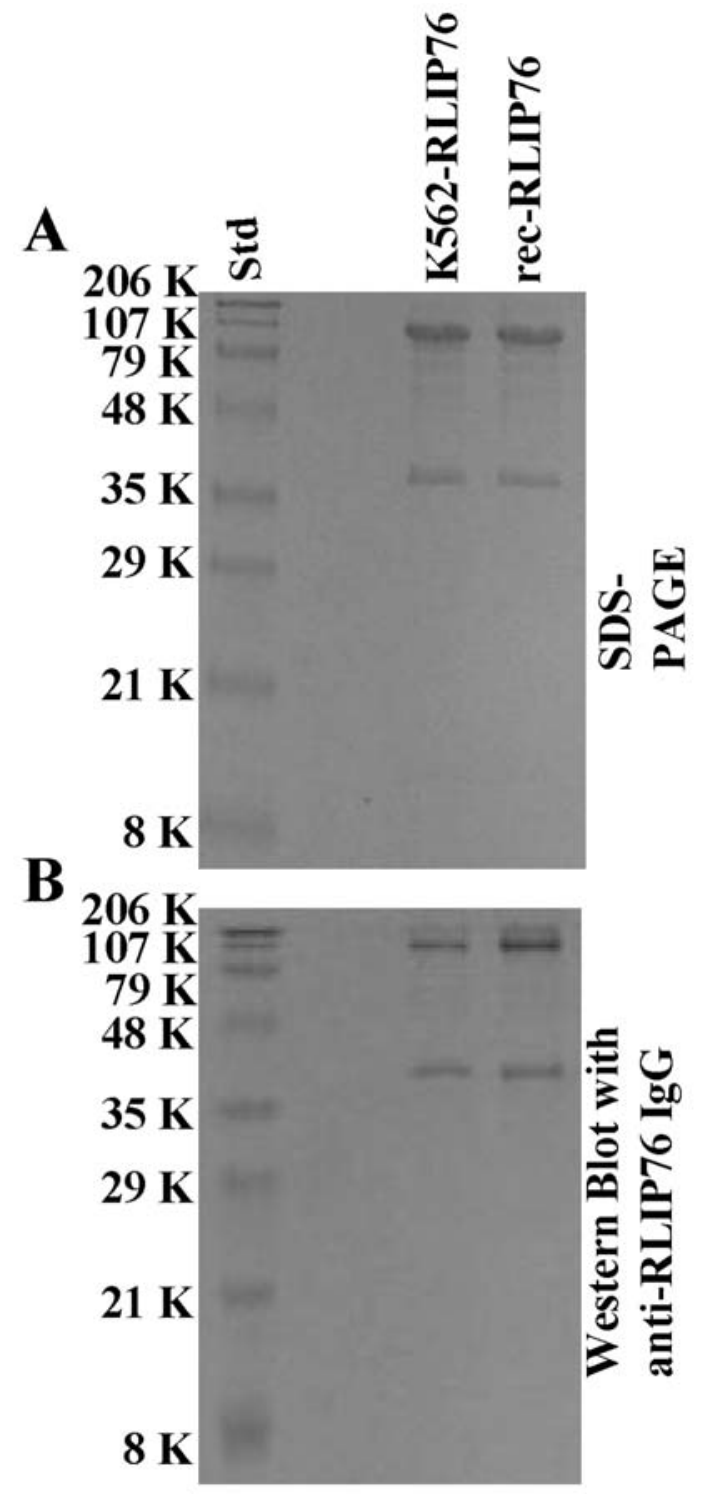

Figure 1. Purification of RLIP76 from K562 cells and transformed E. coli. DNPSG-affinity purified RLIP76 from K562 cells and recombinant source $(\sim 5 \mu \mathrm{g}$ each) were applied to SDS-PAGE and subjected to Western blot analyses against rabbit anti-RLIP76 IgG as a primary antibody. SDS-PAGE was stained with Coomassie brilliant blue-R250 and Western blots were developed using horseradish peroxidase-conjugated goat anti-rabbit-IgG as secondary antibody.

electron microscopy and intra-vesicular volume was estimated by ${ }^{14} \mathrm{C}$-inulin trapping (10).

Transfection of K562 cells. K562 cells were transfected with RLIP76 using a Lipofectamine 2000 transfection reagent kit (Invitrogen). Expression of RLIP76 mRNA in K562 cells was evaluated by RT-PCR analysis. Overexpression of RLIP76 protein in K562 cells was evaluated by applying $100 \mu \mathrm{g}$ of crude membrane extract to SDS-PAGE, followed by Western blot analyses using anti-RLIP76 IgG as a primary antibody. Fold induction of RLIP76 was quantified by scanning densitometry.

Preparation of inside-out vesicles (IOV). Crude membrane vesicles (inside-out vesicles, IOV) were prepared from the 
Table I. Purification of RLIP76 from human erythroleukemia K562 cells.

\begin{tabular}{|c|c|c|c|c|c|c|c|c|c|}
\hline \multirow[b]{2}{*}{ Fraction } & \multicolumn{2}{|c|}{$\begin{array}{l}\text { Total stimulated } \\
\text { ATPase activity } \\
\text { (mU) }\end{array}$} & \multirow[t]{2}{*}{$\begin{array}{l}\text { Total } \\
\text { protein } \\
(\mathrm{mg})\end{array}$} & \multicolumn{2}{|c|}{$\begin{array}{c}\text { Stimulated specific } \\
\text { activity }(\mathrm{mU} / \mathrm{mg} \\
\text { protein })\end{array}$} & \multicolumn{2}{|c|}{$\begin{array}{l}\text { Yield } \\
(\%)\end{array}$} & \multicolumn{2}{|c|}{$\begin{array}{c}\text { Purification } \\
\text { (fold) }\end{array}$} \\
\hline & DNP-SG & GS-HNE & & DNP-SG & GS-HNE & DNP-SG & GS-HNE & DNP-SG & GS-HNE \\
\hline $\begin{array}{l}\text { Detergent } \\
\text { solubilized }\end{array}$ & 3.8 & 2.7 & 5.6 & 0.68 & 0.48 & 100 & 100 & - & - \\
\hline $\begin{array}{l}\text { DNP-SG } \\
\text { affinity }\end{array}$ & 2.1 & 1.9 & 0.032 & 66 & 59 & 55 & 70 & 97 & 123 \\
\hline
\end{tabular}

Purifications were performed with $100 \times 10^{6}$ cells in log phase growth. One milliunit (mU) of enzyme catalyzed 1 nmol ATP hydrolysis per min at $37^{\circ} \mathrm{C}$. DNP-SG and GS-HNE stimulated activity was obtained by subtracting the basal ATPase activities of the fractions determined in the absence of DNP-SG and GS-HNE from the activities determined in the presence of $120 \mu \mathrm{M}$ DNP-SG and $10 \mu \mathrm{M}$ GS-HNE. Basal ATPase activity of this fraction was $111 \mathrm{nmol} / \mathrm{min} / \mathrm{mg}$ protein, and was increased to 177 and $170 \mathrm{nmol} / \mathrm{min} / \mathrm{mg}$, in the presence of $120 \mu \mathrm{M}$ DNP-SG and $10 \mu \mathrm{M}$ GS-HNE, respectively. Relative standard deviations were $<8 \%$ in all cases.

K562 cells using established procedures as described by us for the human erythrocytes (8). Crude vesicles were enriched for the inside-out vesicles by passing over a wheat germ agglutinin-Sepharose column, which selectively retains the right side-out vesicles.

Transport studies in RLIP76-proteoliposomes. Transport studies of ${ }^{3} \mathrm{H}-\mathrm{DNPSG}$ and ${ }^{3} \mathrm{H}-\mathrm{GSHNE}$ in reconstituted vesicles were performed by the method as described by us using $250 \mathrm{ng}$ protein per $30 \mu \mathrm{l}$ reaction mixture. ATP-dependent uptake of ${ }^{3} \mathrm{H}$-DNPSG (specific activity $3.6 \times 10^{3} \mathrm{cpm} / \mathrm{nmol}$, use $100 \mu \mathrm{M}$ final concentration) or ${ }^{3} \mathrm{H}-\mathrm{GSHNE}$ (specific activity $3.5 \times 10^{4} \mathrm{cpm} / \mathrm{nmol}$, use $10 \mu \mathrm{M}$ final concentration) were determined by subtracting the radioactivity $(\mathrm{cpm})$ of the control without ATP from that of the experimental containing ATP, and the transport of DNP-SG or GS-HNE was calculated in terms of $\mathrm{nmol} / \mathrm{min} / \mathrm{mg}$ protein. Liposomes prepared without addition of RLIP76 were used for controls (14).

Transport studies in IOVs. Transport studies in IOV were performed as described previously using $20 \mu \mathrm{g}$ protein per $30 \mu 1$ reaction mixture $(8,13)$. ATP-dependent uptake of ${ }^{3} \mathrm{H}-\mathrm{DNPSG}$ (specific activity $3.6 \times 10^{3} \mathrm{cpm} / \mathrm{nmol}$, use $100 \mu \mathrm{M}$ final concentration) and ${ }^{3} \mathrm{H}-\mathrm{GSHNE}$ (specific activity $3.5 \times 10^{4} \mathrm{cpm} / \mathrm{nmol}$, use $10 \mu \mathrm{M}$ final concentration) were determined by subtracting the radio-activity (cpm) of the control without ATP from that of the experimental containing ATP, and the transport rate was calculated in terms of pmol/ $\mathrm{min} / \mathrm{mg}$ protein. In one of the controls, IOV was excluded while the other control was incubated with an equal amount of heat-inactivated IOV. Each determination was performed in triplicate.

Drug-sensitivity assay. Cell density measurements were performed using a hemocytometer to count reproductive cells resistant to staining with trypan blue. Approximately 20,000 cells were seeded into each well of 96-well plates containing $160 \mu \mathrm{l}$ medium. Post $24 \mathrm{~h}$ incubation, $40 \mu \mathrm{l}$ aliquots of $4 \mathrm{HNE}$ concentrations ranging from 0.1 to $20 \mu \mathrm{M}$ were then added to eight replicate wells to assess the $\mathrm{IC}_{50}$ of $4 \mathrm{HNE}$, defined as the concentration at which formazan reduced by $50 \%$. After $96 \mathrm{~h}$ of incubation, $20 \mu \mathrm{l}$ of $5 \mathrm{mg} / \mathrm{ml} \mathrm{MTT}$ was introduced to each well and incubated for $2 \mathrm{~h}$. The plates were centrifuged and medium was decanted. Cells were subsequently dissolved in $100 \mu \mathrm{l}$ DMSO with gentle shaking for $2 \mathrm{~h}$ at room temperature, followed by measurement of OD at $570 \mathrm{~nm}$ (3).

Statistical methods. All data were evaluated with a two-tailed unpaired Student's t-test or compared by one-way ANOVA and are expressed as the mean $\pm \mathrm{SD}$. A value of $\mathrm{P}<0.05$ was considered statistically significant.

\section{Results and Discussion}

Purification of RLIP76 from recombinant and $K 562$ cells. We purified recombinant human RLIP76 expressed in E. coli and from K562 human erythroleukemia cells. SDS-PAGE and Western blot analyses of DNPSG-Sepharose 4B affinity purified RLIP76 fraction are presented (Fig. 1). Intact RLIP76 was observed at $95 \mathrm{kDa}$, confirmed by $\mathrm{N}$-terminal sequencing. In contrast, $38 \mathrm{kDa}$ peptide band could also be detected in both, recombinant as well as in K562 cells in SDS-PAGE and this $38 \mathrm{kDa}$ band was recognized by anti-RLIP76 antibodies in Western blotting. No significant contaminant protein bands were observed in SDS-PAGE and the pattern of bands in Western blot was identical to that seen in SDS-PAGE (Fig. 1).

Comparison of ATPase activity of human K562 cells vs. recombinant RLIP76. DNPSG-affinity chromatography was monitored by measurements of basal and substrate-stimulated ATPase activity (Tables I and II, respectively). The yield of $32 \mu \mathrm{g}$ purified RLIP76 from $100 \times 10^{6} \mathrm{~K} 562$ cells was consistent with our previous studies with lung cancer cells (11). Basal ATPase activity of RLIP76 purified from K562 cells was $111 \mathrm{nmol} / \mathrm{min} / \mathrm{mg}$, which was stimulated 1.6-fold $(177 \mathrm{nmol} / \mathrm{min} / \mathrm{mg})$ in the presence of DNP-SG and 1.5-fold $(170 \mathrm{nmol} / \mathrm{min} / \mathrm{mg}$ ) in the presence of GS-HNE (Table I). The basal ATPase activity of purified RLIP76 from E. coli was 
Table II. Purification of recombinant RLIP76 from transformed E. coli.

\begin{tabular}{|c|c|c|c|c|c|c|c|c|c|}
\hline \multirow[b]{2}{*}{ Fraction } & \multicolumn{2}{|c|}{$\begin{array}{l}\text { Total stimulated } \\
\text { ATPase activity } \\
\text { (mU) }\end{array}$} & \multirow[t]{2}{*}{$\begin{array}{l}\text { Total } \\
\text { protein } \\
(\mathrm{mg})\end{array}$} & \multicolumn{2}{|c|}{$\begin{array}{c}\text { Stimulated specific } \\
\text { activity }(\mathrm{mU} / \mathrm{mg} \\
\text { protein })\end{array}$} & \multicolumn{2}{|c|}{$\begin{array}{l}\text { Yield } \\
(\%)\end{array}$} & \multicolumn{2}{|c|}{$\begin{array}{l}\text { Purification } \\
\text { (fold) }\end{array}$} \\
\hline & DNP-SG & GS-HNE & & DNP-SG & GS-HNE & DNP-SG & GS-HNE & DNP-SG & GS-HNE \\
\hline $\begin{array}{l}\text { Detergent } \\
\text { extract }\end{array}$ & 112.7 & 27.7 & 38.6 & 2.9 & 0.72 & 100 & 100 & - & - \\
\hline $\begin{array}{l}\text { DNP-SG } \\
\text { affinity }\end{array}$ & 35.8 & 16.8 & 0.18 & 199 & 93 & 32 & 61 & 69 & 129 \\
\hline
\end{tabular}

Two hundred $\mathrm{ml}$ of $E$. coli culture was used for purification. One milliunit (mU) of enzyme catalyzed 1 nmol ATP hydrolysis per min at $37^{\circ} \mathrm{C}$. DNP-SG and GS-HNE stimulated activity was obtained by subtracting the basal ATPase activities of the fractions determined in the absence of DNP-SG and GS-HNE from the activities determined in the presence of $120 \mu \mathrm{M}$ DNP-SG and $10 \mu \mathrm{M}$ GS-HNE. Basal ATPase activity of this fraction was $162 \mathrm{nmol} / \mathrm{min} / \mathrm{mg}$ protein, and was increased to 361 and $255 \mathrm{nmol} / \mathrm{min} / \mathrm{mg}$, in the presence of $120 \mu \mathrm{M}$ DNP-SG and $10 \mu \mathrm{M}$ GS-HNE, respectively. Relative standard deviations were $<8 \%$ in all cases.
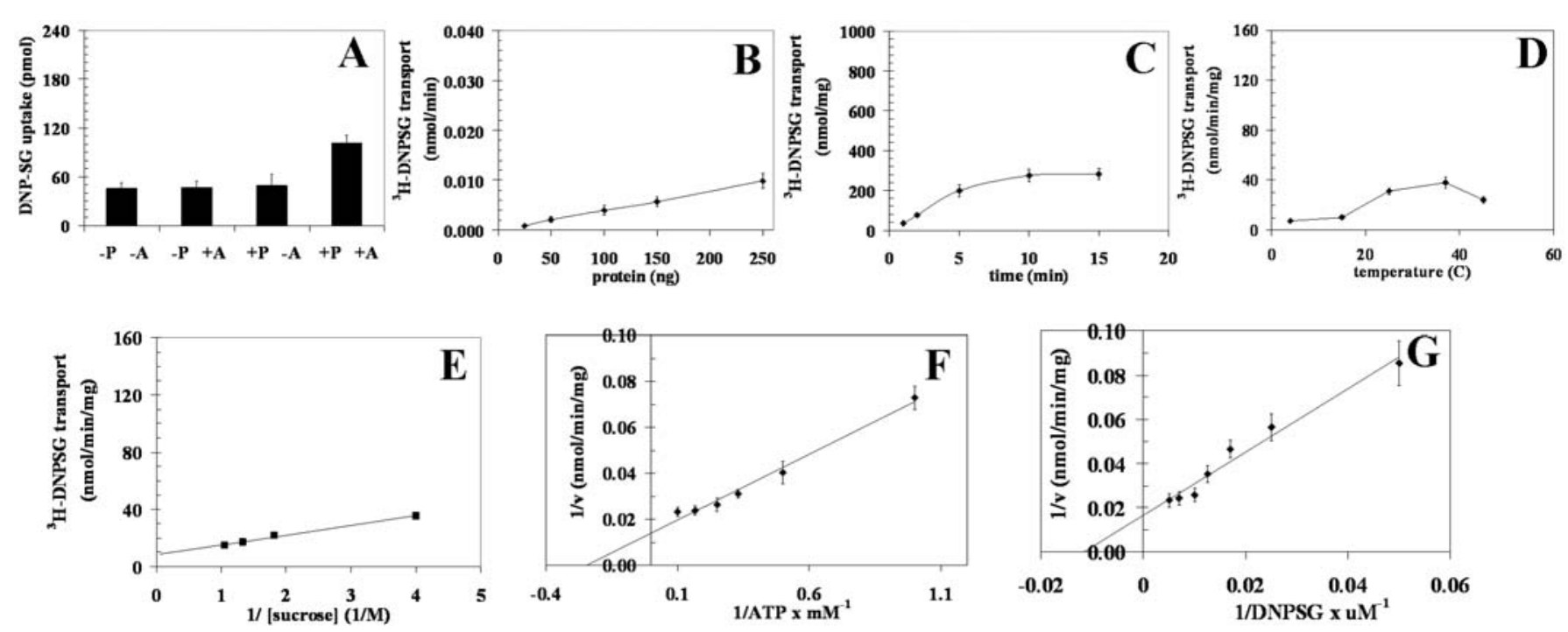

Figure 2. Transport of ${ }^{3} \mathrm{H}$-DNPSG by RLIP76 purified from K562 cells. Purified RLIP76 was reconstituted into artificial liposomes and uptake of radiolabeled ${ }^{3} \mathrm{H}$-DNP-SG by control- or RLIP76-proteoliposomes was measured in the presence or absence of ATP. Vesicles equivalent to 250 ng of purified RLIP76 were used per $30 \mu \mathrm{l}$ filtered reaction mixture in all panels except B. Total radioactivity retained by $0.45 \mu \mathrm{m}$ filters in 96 -well plates was determined after solubilizing filters in scintillation fluid, converted to pmol using the specific activity of ${ }^{3} \mathrm{H}-\mathrm{DNPSG}\left(3.6 \times 10^{3} \mathrm{cpm} / \mathrm{nmol}\right)$. Each point represents an average and SD calculated from 12 measurements [control (-P) or RLIP76-proteoliposomes (+P), without (-A) or with ATP (+A), in triplicates]. Uptake in RLIP76-proteoliposomes with ATP is significantly greater than other groups $(\mathrm{p}<0.005)$ (panel A). All transport studies were carried out using 250 ng protein/assay except when protein was varied (panel B). Incubation time was 5 min except for time-dependence studies (panel $\mathrm{C}$ ). Temperature was $37^{\circ} \mathrm{C}$ except for temperature-dependence studies (panel D). External sucrose concentration was $40 \mathrm{mM}$, except for studies of osmolarity dependence (panel E). ATP was $4 \mathrm{mM}$ except in ATP-dependence studies (panel F). DNP-SG was $100 \mu \mathrm{M}$ except in DNPSG-dependence studies (panel G). The proteoliposomes prepared from RLIP76 purified from K562 cells. Mean values \pm SD for three experiments are shown.

$162 \mathrm{nmol} / \mathrm{min} / \mathrm{mg}$, which was stimulated 2.2-fold (361 nmol/ $\mathrm{min} / \mathrm{mg}$ ) by DNP-SG and 1.6 -fold $(255 \mathrm{nmol} / \mathrm{min} / \mathrm{mg})$ in the presence of GS-HNE (Table II). The basal as well as substratestimulated ATPase activities of RLIP76 purified from transformed $E$. coli were significantly higher $(\mathrm{p}<0.005, \mathrm{n}=6)$ than those of the corresponding activities of RLIP76 from K562 cells.

Comparison of transport activity of human K562 cells vs. recombinant RLIP76. Proteoliposomes were reconstituted with recombinant or K562 RLIP76 purified by using DNP-SG affinity column. Detailed transport kinetics of ATP-dependent ${ }^{3} \mathrm{H}-\mathrm{DNPSG}$ and ${ }^{3} \mathrm{H}-\mathrm{GSHNE}$ were compared. For transport studies with K562 RLIP76 (Figs. 2 and 3), uptake of ${ }^{3} \mathrm{H}-\mathrm{DNPSG}$ and ${ }^{3} \mathrm{H}-\mathrm{GSHNE}$, with or without ATP, was measured in proteoliposomes reconstituted with purified RLIP76. Control liposomes were reconstituted in the presence of an equal amount of crude protein. Uptake with or without ATP in RLIP76 vs. control-liposomes are shown for K562 cells (Fig. 2 for DNP-SG and Fig. 3 for GS-HNE, panels A-G). The presence of ATP caused an increase in uptake of ${ }^{3} \mathrm{H}$-DNPSG and ${ }^{3} \mathrm{H}-\mathrm{GSHNE}$ only in proteo- 

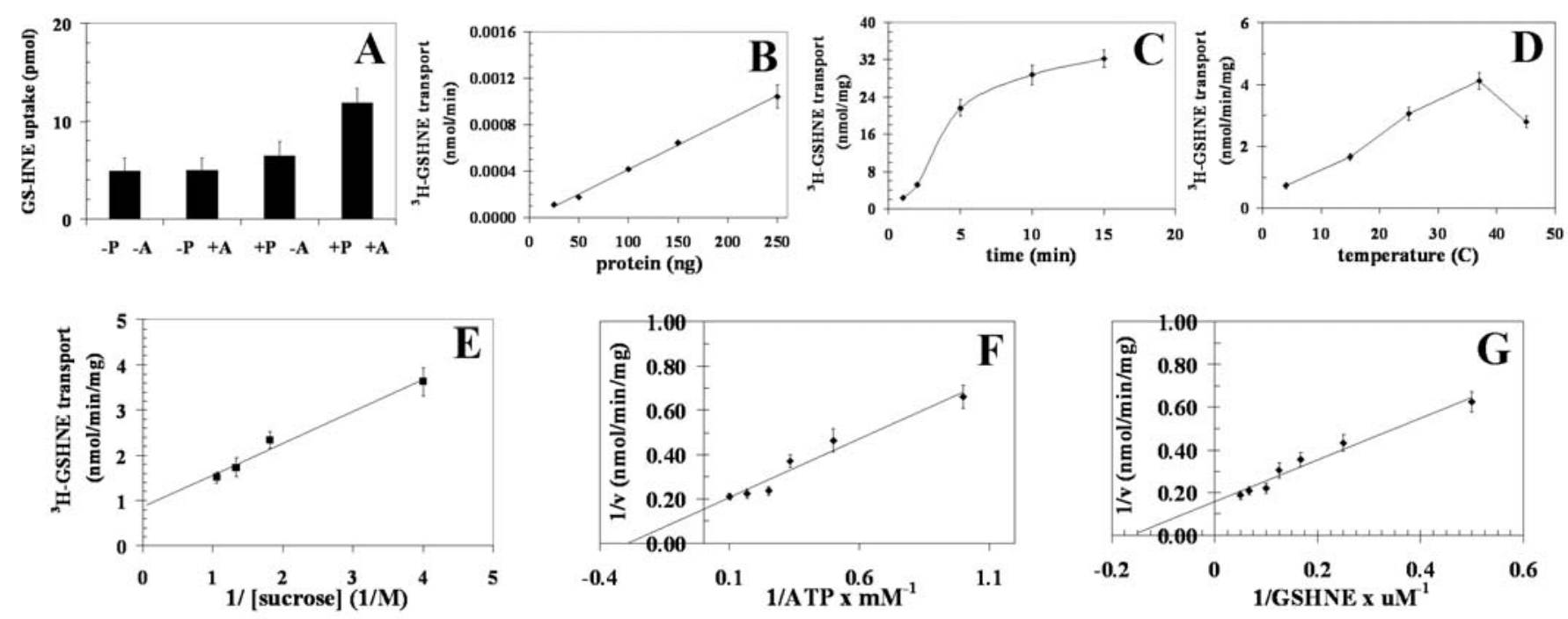

Figure 3. Transport of ${ }^{3} \mathrm{H}-$ GS-HNE by RLIP76 purified from K562 cells. Transport studies were carried out as described in Fig. 2 . The uptake of radio-labeled ${ }^{3} \mathrm{H}-\mathrm{GSHNE}$ by control- or RLIP76-proteoliposomes was measured in the presence or absence of ATP. Total radioactivity retained by $0.45 \mu \mathrm{m}$ filters in 96-well plates was determined after solubilizing filters in scintillation fluid, converted to pmol using the specific activity of ${ }^{3} \mathrm{H}-\mathrm{GSHNE}$ ( $3.5 \mathrm{x} 10^{4} \mathrm{cpm} / \mathrm{nmol}$ ). The proteoliposomes prepared from RLIP76 purified from K562 cells. Mean values \pm SD for three experiments are shown.
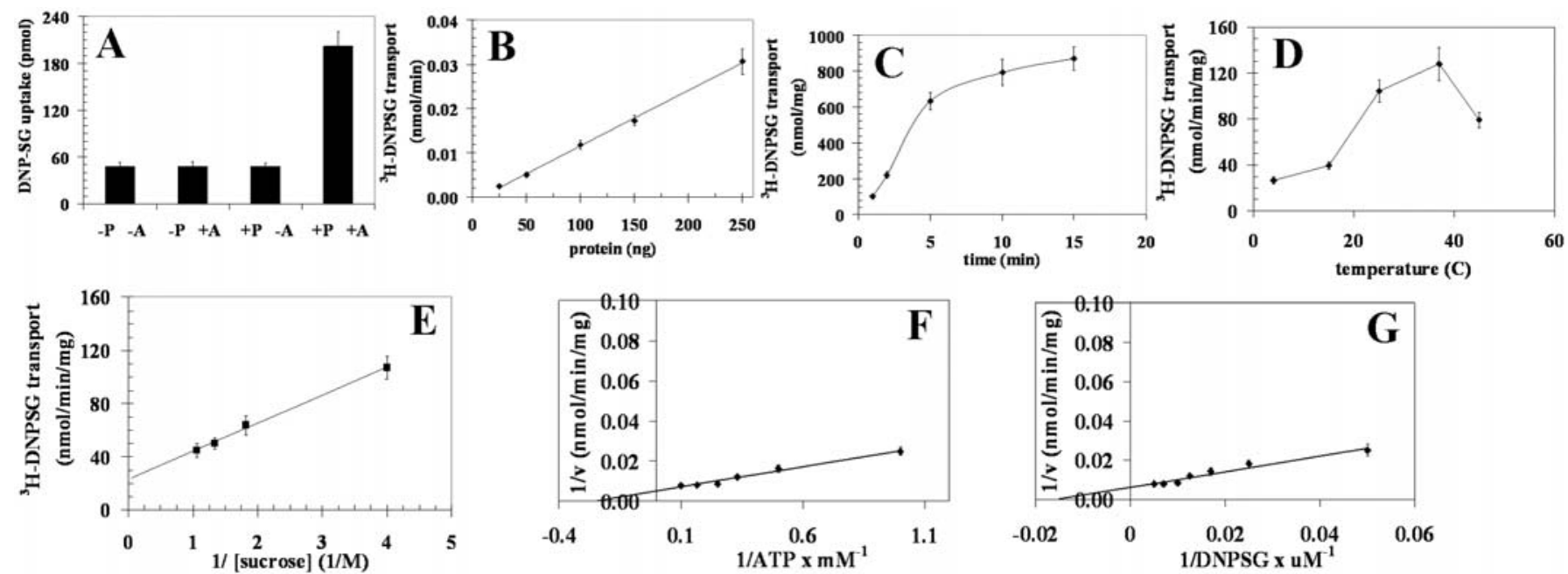

Figure 4. Transport of ${ }^{3} \mathrm{H}$-DNPSG by RLIP76 purified from transformed E. coli. Transport studies were carried out as described in Fig. 2. The uptake of radio-labeled ${ }^{3} \mathrm{H}$-DNP-SG by control- or RLIP76-proteoliposomes was measured in the presence or absence of ATP. Total radioactivity retained by $0.45 \mu \mathrm{m}$ filters in 96-well plates was determined after solubilizing filters in scintillation fluid, converted to pmol using the specific activity of ${ }^{3} \mathrm{H}-\mathrm{DNPSG}$ $\left(3.6 \times 10^{3} \mathrm{cpm} / \mathrm{nmol}\right)$. The proteoliposomes prepared from RLIP76 purified from transformed E. coli. Mean values \pm SD for three experiments are shown.

liposomes reconstituted with RLIP76 and not in control liposomes (Figs. 2A and 3A). ATP-dependent uptake of ${ }^{3} \mathrm{H}-$ DNPSG and ${ }^{3} \mathrm{H}-\mathrm{GSHNE}$ were linear with respect to the amount of RLIP76 used for reconstitution of vesicles (Figs. $2 \mathrm{~B}$ and $3 \mathrm{~B})$. The uptake was time dependent in a manner consistent with uptake by a single compartment (Figs. 2C and $3 \mathrm{C}$ ). The transport was temperature sensitive with an optimal near $37^{\circ} \mathrm{C}$ (Figs. 2D and 3D), and sensitive to osmolarity of extra-vesicular medium (Figs. 2E and 3E). Saturable kinetics for the transport by these proteoliposomes was observed for both ATP (Figs. 2F and 3F) and DNP-SG and GS-HNE (Figs. 2G and 3G). All transport studies with K562 RLIP76-proteoliposomes indicated that ${ }^{3} \mathrm{H}-\mathrm{DNPSG}$ and ${ }^{3} \mathrm{H}-\mathrm{GSHNE}$ uptake were identical in control-liposomes in the absence or presence of ATP, and equal to the uptake observed in RLIP76-proteoliposomes in the absence of ATP (Figs. 2A and 3A). Since background binding of DNPSG and GSHNE to the filtration membranes was unaffected by the presence of liposomes or nucleotides, its exclusion had no effect on calculations of ATP-dependent uptake rates. Please note the differences in scales between the Figs. 2 and 3.

Thus, ${ }^{3} \mathrm{H}-\mathrm{DNPSG}$ and ${ }^{3} \mathrm{H}-\mathrm{GSHNE}$ transport with recombinant RLIP76 was measured by subtracting ${ }^{3} \mathrm{H}-\mathrm{DNPSG}$ and ${ }^{3} \mathrm{H}$-GSHNE uptake in recombinant RLIP76-proteoliposomes in the absence of ATP from that observed in its presence (Figs. 4 for DNP-SG and 5 for GS-HNE, panels A-G). As with K562 RLIP76, ${ }^{3} \mathrm{H}-\mathrm{DNPSG}$ and ${ }^{3} \mathrm{H}-\mathrm{GSHNE}$ transport by recombinant RLIP76 was linearly increased with protein used 

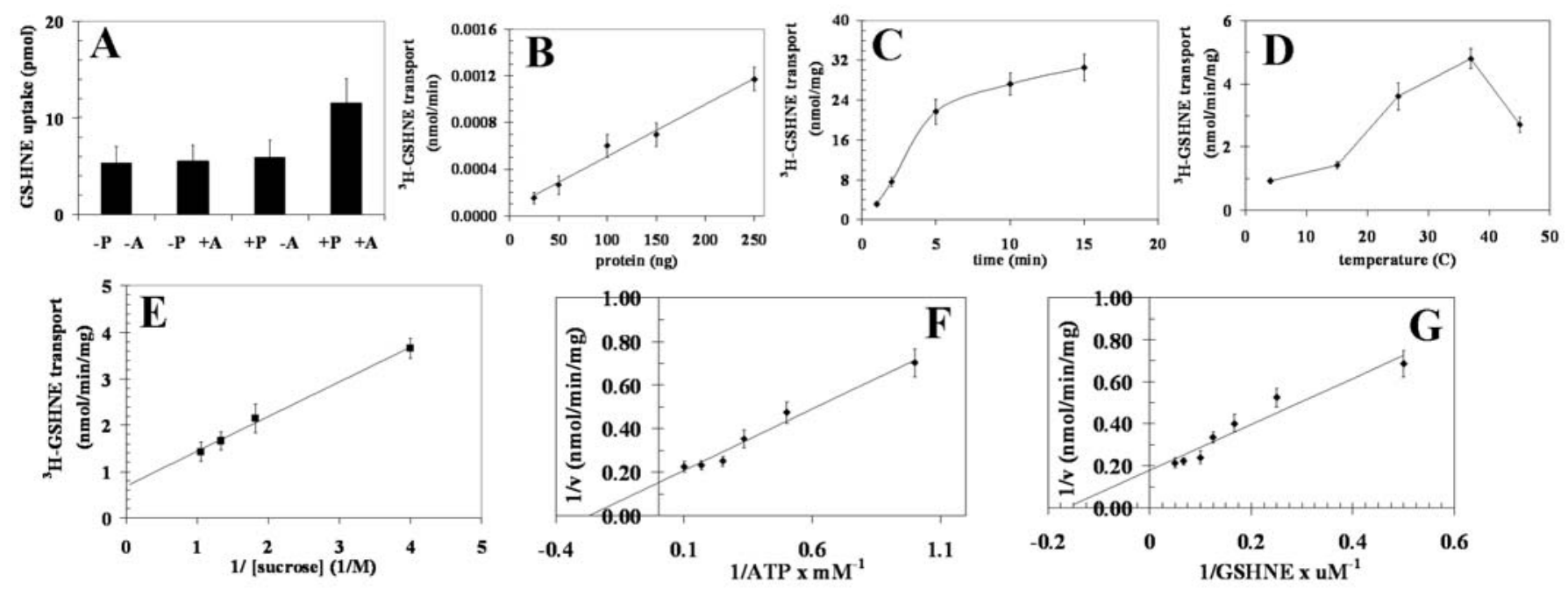

Figure 5. Transport of ${ }^{3} \mathrm{H}-$ GSHNE by RLIP76 purified from transformed E. coli. Transport studies were carried out as described in Fig. 2. The uptake of radio-labeled ${ }^{3} \mathrm{H}$-GSHNE by control- or RLIP76-proteoliposomes was measured in the presence or absence of ATP. Total radioactivity retained by $0.45 \mu \mathrm{m}$ filters in 96-well plates was determined after solubilizing filters in scintillation fluid, converted to pmol using the specific activity of ${ }^{3} \mathrm{H}-\mathrm{GSHNE}$ $\left(3.5 \times 10^{4} \mathrm{cpm} / \mathrm{nmol}\right)$. The proteoliposomes prepared from RLIP76 purified from transformed $E$. coli. Mean values \pm SD for three experiments are shown.

Table III. Comparison of ATPase activity and kinetics parameters of glutathione-conjugate transport by RLIP76 purified from human erythroleukemia K562 cells and transformed E. coli.

\begin{tabular}{lcc}
\hline Parameters & K562 RLIP76 & Recombinant RLIP76 \\
\hline ATPase activity & & $199 \pm 14$ \\
DNP-SG stimulated $(\mathrm{nmol} / \mathrm{min} / \mathrm{mg})$ & $66 \pm 5$ & $93 \pm 6$ \\
GS-HNE stimulated $(\mathrm{nmol} / \mathrm{min} / \mathrm{mg})$ & $59 \pm 3$ & \\
${ }^{3} \mathrm{H}-\mathrm{DNPSG}$ transport & & $4.4 \pm 0.7$ \\
$\mathrm{~K}_{\mathrm{m}}$ for ATP $(\mathrm{mM})$ & $4.2 \pm 0.3$ & $55 \pm 4$ \\
$\mathrm{~K}_{\mathrm{m}}$ for DNPSG $(\mu \mathrm{M})$ & $80 \pm 6$ & $155 \pm 11$ \\
$\mathrm{~V}_{\max }$ of DNPSG transport $(\mathrm{nmol} / \mathrm{min} / \mathrm{mg})$ & $61 \pm 5$ & \\
${ }^{3} \mathrm{H}-\mathrm{GSHNE}$ transport & & $3.5 \pm 0.2$ \\
$\mathrm{~K}_{\mathrm{m}}$ for ATP $(\mathrm{mM})$ & $2.8 \pm 0.2$ & $7 \pm 1$ \\
$\mathrm{~K}_{\mathrm{m}}$ for GSHNE $(\mu \mathrm{M})$ & $6 \pm 1$ & $6.2 \pm 0.4$ \\
$\mathrm{~V}_{\max }$ of GSHNE transport $(\mathrm{nmol} / \mathrm{min} / \mathrm{mg})$ & $5.4 \pm 0.6$ & \\
\hline
\end{tabular}

for transport studies (Figs. 4B and 5B), was time-dependent and consistent with uptake into a single compartment (Figs. 4C and $5 \mathrm{C}$ ), sensitive to temperature with an optimal near $37^{\circ} \mathrm{C}$ (Figs. 4D and 5D), sensitive to osmolarity of extra-vesicular medium (Figs. 4E and 5E), saturable with respect to ATP (Figs. 4F and 5F) and DNP-SG and GS-HNE (Figs. 4G and $5 \mathrm{G})$. Please note the differences in scales between Figs. 4 and 5. Collectively, increased ${ }^{3} \mathrm{H}-\mathrm{DNPSG}$ and ${ }^{3} \mathrm{H}-\mathrm{GSHNE}$ uptake was demonstrable only in the presence of both RLIP76proteoliposomes and ATP and not in control-liposomes without or with ATP, or in RLIP76-proteoliposomes without ATP (Figs. 2A, 3A, 4A and 5A).

Kinetic properties of ${ }^{3} \mathrm{H}-D N P S G$ and ${ }^{3} \mathrm{H}-\mathrm{GSHNE}$ transport by K562 and recombinant RLIP76 showed interesting similarities and differences (Table III). Both transporters had a temperature optimum near $37^{\circ} \mathrm{C}$, and the $\mathrm{K}_{\mathrm{m}}$ values for ATP, DNP-SG and GS-HNE differed slightly, but not significantly. The $\mathrm{V}_{\max }$ calculated by fitting a two-substrate random bi-bi sequential kinetic model (61 vs. $155 \mathrm{nmol} / \mathrm{min} / \mathrm{mg}$ for DNP-SG transport, 5.4 vs. $6.2 \mathrm{nmol} / \mathrm{min} / \mathrm{mg}$ for GS-HNE transport, for the K562 and recombinant protein, respectively) were expectedly significantly greater than the measured activities, because ATP and GS-E concentrations used for routine activity assays are significantly below saturating concentrations. However, the ATPase activity as well as calculated $\mathrm{V}_{\max }$ for ${ }^{3} \mathrm{H}-\mathrm{DNPSG}$ and ${ }^{3} \mathrm{H}-\mathrm{GSHNE}$ transport was significantly greater for recombinant as compared with K562 RLIP76. These observations could be explained by either the presence of additional activating factors in purified recombinant RLIP76 fraction, potential inhibitors present in the purified K562 

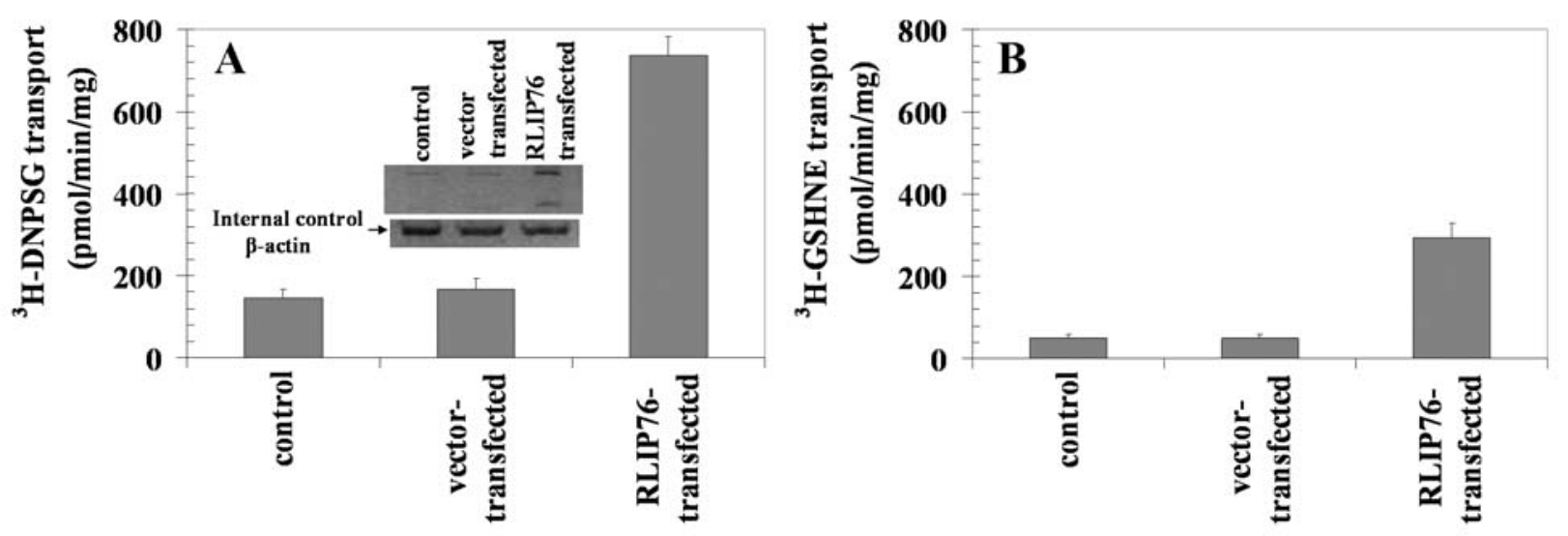

Figure 6. Effect of RLIP76 transfection on ${ }^{3} \mathrm{H}-\mathrm{DNPSG}$ and ${ }^{3} \mathrm{H}-\mathrm{GSHNE}$ transport in inside-out vesicles (IOV) prepared from K562 cells The overexpression of RLIP76 in K562 cells was confirmed by Western blot analyses using anti-RLIP76 IgG. ß-actin was used as internal control (inset). ATP-dependent uptake of ${ }^{3} \mathrm{H}$-DNPSG (panel A) and ${ }^{3} \mathrm{H}-\mathrm{GSHNE}$ (panel B) were determined in inside-out plasma membrane vesicles prepared from control, vector (pcDNA3)transfected and RLIP76-transfected K562 cells. Standard conditions were $20 \mu \mathrm{g}$ IOV protein, 10 min incubation time, $37^{\circ} \mathrm{C}$ temperature, 40 mM sucrose, $4 \mathrm{mM}$ ATP and $100 \mu \mathrm{M}$ DNPSG or $10 \mu \mathrm{M}$ GSHNE. Each value represents mean of triplicate determinations with error bars representing standard deviations.

Table IV. Comparison of glutathione-conjugate transport capacity in crude membrane vesicles prepared from human erythroleukemia K562 cells and by RLIP76 purified from K562 cells and transformed E. coli.

\begin{tabular}{|c|c|c|c|}
\hline Fraction & ${ }^{3} \mathrm{H}-\mathrm{DNPSG}$ transport & ${ }^{3} \mathrm{H}-\mathrm{GSHNE}$ transport & $\mathrm{IC}_{50}$ for $4-\mathrm{HNE}$ \\
\hline K562 cells purified RLIP76 & $39.4 \pm 2.6 \mathrm{nmol} / \mathrm{min} / \mathrm{mg}$ & $4.2 \pm 0.3 \mathrm{nmol} / \mathrm{min} / \mathrm{mg}$ & \\
\hline Recombinant purified RLIP76 & $125 \pm 14 \mathrm{nmol} / \mathrm{min} / \mathrm{mg}$ & $4.8 \pm 0.4 \mathrm{nmol} / \mathrm{min} / \mathrm{mg}$ & \\
\hline \multicolumn{4}{|l|}{ IOVs from: } \\
\hline Control K562 cells & $147 \pm 11 \mathrm{pmol} / \mathrm{min} / \mathrm{mg}$ & $51 \pm 4 \mathrm{pmol} / \mathrm{min} / \mathrm{mg}$ & $1.8 \pm 0.2 \mu \mathrm{M}$ \\
\hline Vector-transfected K562 cells & $166 \pm 18 \mathrm{pmol} / \mathrm{min} / \mathrm{mg}$ & $56 \pm 6 \mathrm{pmol} / \mathrm{min} / \mathrm{mg}$ & $2.0 \pm 0.2 \mu \mathrm{M}$ \\
\hline RLIP76-transfected K562 cells & $738 \pm 42 \mathrm{pmol} / \mathrm{min} / \mathrm{mg}$ & $294 \pm 31 \mathrm{pmol} / \mathrm{min} / \mathrm{mg}$ & $9.4 \pm 0.6 \mu \mathrm{M}$ \\
\hline
\end{tabular}

Inside-out vesicles were prepared from K562 cells according to the protocol as described by us previously (8). RLIP76 was purified by DNP-SG affinity column chromatography from K562 cells as well as from recombinant source and reconstituted into artificial liposomes to perform transport studies.

RLIP76 fraction, or lack of certain essential post-translational modifications in RLIP76 from K562 cells. Additional studies are needed to address this question.

Overexpression of RLIP76 in K562. Overexpression of RLIP76 was achieved in K562 cells as confirmed by Western blot analyses against anti-RLIP76 IgG (Fig. 6, inset). Quantifying RLIP76 protein by ELISA assay showed a $\sim 4$-fold increase in RLIP76 protein in overexpressing cells as compared to control or empty vector transfected cells.

Effect of RLIP76 overexpression on $4 H N E$ resistance and $G S$-E transport in IOVs. Cytotoxicity assays were performed to examine the effects of RLIP76 transfection on resistance to $4 \mathrm{HNE}$ in $\mathrm{K} 562$ cells. The wild-type, empty-vector or RLIP76 transfected cell $\mathrm{IC}_{50}$ was determined $96 \mathrm{~h}$ after addition of 4HNE. Whereas empty-vector transfection had little or no effect, RLIP76 overexpression yielded $\sim 5$-fold resistance to the cytotoxic effects for 4HNE, suggesting the overexpression of RLIP76 confers resistance in K562 cells against 4HNE (Table IV). Abrogation of this resistance by anti-RLIP76 antibodies further indicates that this effect is specifically mediated by RLIP76.

To determine whether the acquired resistance of transfected cells was due to enhanced RLIP76-mediated efflux, we conducted transport studies. Transport of ${ }^{3} \mathrm{H}-\mathrm{DNPSG}$ and ${ }^{3} \mathrm{H}-\mathrm{GSHNE}$ was compared between wild-type, empty-vector or RLIP76 transfected K562 cells IOVs using established methods $(8,14)$. A marked increase $(\sim 5$-fold $)$ in ATPdependent transport of both GS-Es was observed in IOVs prepared from cells overexpressing RLIP76. The emptyvector control was unaffected (Fig. 6 and Table IV). It should be noted that ATP-dependent ${ }^{3} \mathrm{H}-\mathrm{DNPSG}$ and ${ }^{3} \mathrm{H}-\mathrm{GSHNE}$ uptake rate in purified K562 RLIP76-proteoliposomes was $>100$-fold greater than the uptake rate in crude membrane vesicles prepared from K562 cells (Table IV). This is consistent with $>100$-fold purification of RLIP76 by the GS-E affinity column, suggests that RLIP76 represents a significant fraction of total transporter activity in crude membrane vesicles. 
Present studies show that RLIP76 is capable of mediating ATP-dependent transport of GS-E and that increased RLIP76 can confer resistance to $4 \mathrm{HNE}$ in K562 cells. The prototypical and most abundant lipid derived alkenal, 4HNE, is formed from $\beta$-scission of arachidonic acid and other phospholipids after oxidation. It is known to exert proliferative effects in a variety of cultured cells at low concentrations $(<1 \mu \mathrm{M})$, necrosis at very high concentrations (generally $>20 \mu \mathrm{M}$ ), and apoptosis at intermediate levels though the JNK and AP1 pathways (22-24). We have shown that inhibition of RLIP76 increases cellular GS-HNE as well as 4-HNE, and that this also triggers apoptosis through the same pathways. Sub-lethal oxidant or radiant stress (heat, UV) rapidly up-regulates RLIP76 activity and protein, leading to increased GS-E efflux and relative resistance to toxicity of subsequent exposure to either of the stressors $(25,26)$. These studies, taken together with studies in a number of lung and other cancer cell lines which show the induction of apoptosis upon specific inhibition of RLIP76 by antibodies, or specific depletion by siRNA or antisense, even in the absence of any chemotherapy agents, strongly support the assertion by us and others that cellular accumulation of alkenals is a common early step for stress-mediated apoptosis $(3,25,26)$.

These findings demonstrated that RLIP76 is a novel link between the ras-linked cellular signaling pathways and transport-mediated drug-resistance, and suggests that amphiphilic drug substrates could exert toxic or therapeutic effects through competitive inhibition of efflux of physiologic GS-E. Thus, elucidation of RLIP76 function at a molecular level could offer mechanistic insight into a diverse array of incompletely understood biological, toxicological and pharmacological phenomena in which physiologic GS-E participate $(21,27)$. Our studies demonstrate the presence of RLIP76 in K562 cells, and that it functions as a GS-E transporter. GS-E transporters should thus function as an integral component of GSH-linked defenses, which serve the critical function of protecting DNA from lesions caused by reactive electrophiles.

RLIP76 is a multi-functional transporter protein that serves as an energy-dependent efflux mechanism for endogenously generated toxic metabolites as well as exogenous toxins including chemotherapy drugs. Stress signaling though NF-кB is directly mediated by GS-E, specifically by GS-HNE (28). Our findings indicate that RLIP76 is a common effector protein for regulating cellular GS-E levels and that multiple signaling proteins may regulate cell proliferation, differentiation, motility, and apoptosis through modulation of RLIP76 transport activity. Remarkable activity in animal models of melanoma (4), lung and colon cancer (29) strongly indicate sufficient cancer-specific expression and cancer-specific toxicity to warrant consideration of RLIP76 as a therapeutic target for cancer therapy.

\section{Acknowledgements}

This study was supported in part by National Institutes of Health Grants CA 77495 and CA 104661, Cancer Research Foundation of North Texas, Institute for Cancer Research and the Joe and Jessie Crump Fund for Medical Education.

\section{References}

1. Awasthi S, Cheng J, Singhal SS, et al: Novel function of human RLIP76: ATP-dependent transport of glutathione-conjugates and doxorubicin. Biochemistry 39: 9327-9334, 2000.

2. Awasthi S, Singhal SS, Yadav S, et al: RLIP76 is a major determinant of radiation-sensitivity. Cancer Res 65: 6022-6028, 2005.

3. Singhal SS, Yadav S, Singhal J, Zajac E, Awasthi YC and Awasthi, S: Depletion of RLIP76 sensitizes lung cancer cells to doxorubicin. Biochem Pharmacol 70: 481-488, 2005.

4. Singhal SS, Awasthi YC and Awasthi S: Regression of melanoma in a murine model by RLIP76 depletion. Cancer Res 66: 2354-2360, 2006.

5. Jullien-Flores V, Dorseuil O, Romero F, et al: Bridging RalGTPase to Rho-pathways. RLIP76, a Ral-effector with CDC42/ Rac GTPase-activating protein activity. J Biol Chem 270: 22473-22477, 1995.

6. Park SH and Weinberg RA: A putative effector of Ral has homology to Rho/Rac GTPase-activating proteins. Oncogene 11: 2349-2355, 1995

7. Cantor SB, Urano T and Feig LA: Identification and characterization of Ral-binding-protein1, a potential downstream target of Ral GTPases. Mol Cell Biol 15: 4578-4584, 1995.

8. Awasthi S, Singhal SS, Srivastava SK, et al: Adenosinetriphosphate-dependent transport of doxorubicin, daunomyicn, and vinblastine in human tissues by a mechanism distinct from the P-glycoprotein. J Clin Invest 93: 958-965, 1994.

9. Awasthi S, Singhal SS, Srivastava SK, et al: ATP dependent human erythrocyte glutathione-conjugate-transporter. I. Purification, photoaffinity-labeling, and kinetic characteristics of ATPase-activity. Biochemistry 37: 5231-5238, 1998.

10. Awasthi S, Singhal SS, Pikula S, et al: ATP-dependent human erythrocyte glutathione-conjugate-transporter. II. Functional reconstitution of transport-activity. Biochemistry 37: 5239-5248, 1998.

11. Singhal SS, Singhal J, Sharma R, Singh SV, Zimniak P, Awasthi YC and Awasthi S: Role of RLIP76 in lung cancer doxorubicin-resistance: The ATPase activity of RLIP76 correlates with doxorubicin and 4HNE-resistance in lung cancer cells. Int J Oncol 22: 365-375, 2003.

12. Awasthi S, Singhal SS, Sharma R, Zimniak P and Awasthi YC: Transport of glutathione-conjugates and chemotherapeutic drugs by RLIP76: a novel link between G-protein and tyrosine-kinase signaling and drug-resistance. Int J Cancer 106: 635-646, 2003.

13. Stuckler D, Singhal J, Singhal SS, Yadav S, Awasthi YC and Awasthi S: RLIP76 transports vinorelbine and mediates drugresistance in non-small cell lung cancer. Cancer Res 65: 991-998, 2005.

14. Sharma R, Singhal SS, Cheng J, et al: RLIP76 is the major ATP-dependent transporter of glutathione-conjugates and doxorubicin in human erythrocytes. Arch Biochem Biophys 391: 171-179, 2001.

15. Morinaka K, Koyama S, Nakashima S, et al: Epsin binds to the EH domain of POB 1 and regulates receptor-mediated endocytosis. Oncogene 18: 5915-5922, 1999.

16. Rosse C, L'Hoste S, Offner N, Picard A and Camonis JH: RLIP, an effector of the Ral-GTPases, is a platform for Cdk1 to phosphorylate epsin during the switch off of endocytosis in mitosis. J Biol Chem 278: 30597-30604, 2003.

17. Nakashima S, Morinaka K, Koyama S, et al: Small G protein $\mathrm{Ral}$ and its downstream molecules regulate endocytosis of EGF and insulin-receptors. EMBO J 18: 3629-3642, 1999.

18. Oosterhoff JK, Penninkhof F, Brinkmann AO, Grootegoed JA and Blok LG: POB1 is down-regulated during human prostate cancer progression and inhibits growth factor signaling in prostate cancer cells. Oncogene 22: 2920-2925, 2003.

19. Quaroni A and Paul EC: Cytocentrin is a Ral-binding protein involved in the assembly and function of the mitotic-apparatus. J Cell Sci 112: 707-718, 1999.

20. Jakoby WB: The glutathione S-transferases: A group of multifunctional detoxification proteins. Adv Enzymol Mol Biol 46: 383-414, 1978.

21. Awasthi S, Srivastava SK, Ahmad F, Ahmad H and Ansari GAS: Interactions of glutathione S-transferase $\pi$ with ethacrynic acid and its glutathione-conjugate. Biochim Biophys Acta 1164: 173-178, 1993.

22. Sharma R, Brown D, Awasthi S, et al: Transfection with 4HNEmetabolizing glutathione S-transferase isozymes leads to phenotypic transformation and immortalization of adherent cells. Eur J Biochem 271: 1690-1701, 2004. 
23. Cheng J, Singhal SS, Saini M, et al: Apoptosis and differentiation of K562 human erythro-leukemia cells by $4 \mathrm{HNE}$ and the effects of transfection with the 4HNE metabolizing glutathione S-transferase isoenzyme. Arch Biochem Biophys 372: 29-36, 1999.

24. Cheng J, Singhal SS, Sharma A, et al: Transfection of mGSTA4 in HL-60 cells protects against 4HNE-induced apoptosis by inhibiting JNK-mediated signaling. Arch Biochem Biophys 392: 197-207, 2001

25. Cheng J, Sharma R, Yang Y, et al: Accelerated metabolism and exclusion of 4-hydroxy-nonenal through induction of RLIP76 and hGST5.8 is an early adaptive response of cells to heat and oxidative-stress. J Biol Chem 276: 41213-41223, 2001.

26. Yang Y, Sharma A, Sharma R, et al: Cells preconditioned with mild, transient UVA-irradiation acquire resistance to oxidativestress and UVA-induced apoptosis: Role of 4-HNE in UVAmediated signaling for apoptosis. J Biol Chem 278: 41380-41388, 2003.
27. Mertens JJ, Gibson NW, Lau SS and Monks TJ: Reactive oxygen species and DNA damage in 2-bromo-(glutathion-S-yl) hydroquinone-mediated cytotoxicity. Arch Biochem Biophys 320: 51-58, 1995.

28. Ramana KV, Bhatnagar A, Srivastava S, Yadav UC, Awasthi S, Awasthi YC and Srivastava SK: Mitogenic responses of vascular smooth muscle cells to lipid peroxidation-derived aldehyde 4HNE: Role of aldose reductase-catalyzed reduction of the HNE-glutathione conjugates in regulating cell growth. J Biol Chem 281: 17652-17660, 2006.

29. Singhal SS, Singhal J, Yadav S, Dwivedi S, Boor P, Awasthi YC and Awasthi S: Regression of lung and colon cancer xenografts by depleting or inhibiting RLIP76. Cancer Res 67: 4382-4389, 2007. 